\title{
Antifungal activity of a novel chromene dimer
}

\author{
L. Abrunhosa $\cdot$ M. Costa $\cdot$ F. Areias $\cdot$ A. Venâncio $\cdot$ \\ F. Proença
}

Received: 12 April 2007 / Accepted: 29 August 2007 / Published online: 21 September 2007

(C) Society for Industrial Microbiology 2007

\begin{abstract}
The activity on Aspergillus spp. growth and on ochratoxin A production of two novel chromene dimers (3) was evaluated. The results of the bioassays indicate that the chromene dimer 3a inhibited mycelia growth by approximately $50 \%\left(\mathrm{EC}_{50}\right)$ at $140.1 \mu \mathrm{mol} \mathrm{L} \mathrm{L}^{-1}$ for A. niger, $384.2 \mu \mathrm{mol} \mathrm{L}^{-1}$ for A. carbonarius, $69.1 \mu \mathrm{mol} \mathrm{L}^{-1}$ for A. alliaceus and $559.1 \mu \mathrm{mol} \mathrm{L}^{-1}$ for A. ochraceus. When applied at concentrations of $2 \mathrm{mmol} \mathrm{L}^{-1}, \mathbf{3 a}$ totally inhibited the growth of all Aspergillus spp. tested. Furthermore, ochratoxin A production by A. alliaceus was reduced by about $94 \%$ with a $200 \mu \mathrm{mol} \mathrm{L}{ }^{-1}$ solution of this compound. A moderate inhibitory effect was observed for the analogous structure $\mathbf{3 b}$ on ochratoxin A production but not in mycelia growth. No inhibition was registered for compounds $\mathbf{2 a}$ and $\mathbf{2} \mathbf{b}$, used as synthetic precursors of the dimeric species 3 .
\end{abstract}

Keywords Chromenes - Aspergillus spp. Ochratoxin A · Antifungal compounds

\section{Introduction}

The screening for new antifungal chemicals is a constant need, due to the public demand for crop protection agents with low use rates, a benign environmental profile, and low

L. Abrunhosa $\cdot$ A. Venâncio $(\square)$

IBB-Institute for Biotechnology and Bioengineering,

Centre for Biological Engineering, Universidade do Minho,

Campus de Gualtar, 4710-057 Braga, Portugal

e-mail: avenan@deb.uminho.pt

M. Costa $\cdot$ F. Areias $\cdot$ F. Proença $(\square)$

Centro de Química, Universidade do Minho,

Campus de Gualtar, 4710-057 Braga, Portugal toxicity to humans and wildlife. There is also a need for compounds with novel modes of action and improved efficiency, capable to combat pathogens with resistance or reduced sensitivity [10].

The use of fungicides aims at the inhibition of fungal growth and ultimately at the prevention of agricultural commodities deterioration. Nevertheless, when fungi are present the mycotoxins issue is also very important. Recent reports correlate the application of some fungicides with an increase in mycotoxin contents. For example, it was reported that azoxystrobin increased the production of deoxynivalenol per unit of pathogen in an artificially inoculated field trial [16], that miconazole and fenpropimorph increased the aflatoxin production from A. parasiticus in laboratory conditions [7] and that fenhexamid, mancozeb and a mixture of copper salts increased the ochratoxin A (OTA) production by A. carbonarius in grapes [3].

Ochratoxin A is one of the mycotoxins which is frequently reported to be present in crops. It has nephrotoxic, teratogenic, hepatotoxic, immunosuppressive and carcinogenic properties, and it is produced by some Aspergillus and Penicillium species on some specific agricultural commodities. For example, A. carbonarius is mainly responsible for ochratoxin A contamination in grapes [15], $A$. alliaceus for contamination in figs [2], A. ochraceus and A. carbonarius for contamination in green coffee beans [14], $P$. verrucosum in cereal grains [13] and $P$. nordicum in meat and cheese [12]. For this reason, OTA is usually found in food products such as breakfast cereals, coffee, cocoa products, dried vine fruits, dried figs, beer and wine.

Chromene derivatives are an important class of compounds, widely present in plants, including edible vegetables and fruits [6]. The biological activity of some natural chromene-based structures led to the development of synthetic analogues, some of them displaying remarkable 
effects as pharmaceuticals $[1,4,5,9,11,17]$, including antimicrobial agents [8].

In the present work, we tested the activity of two novel chromene dimers on Aspergillus spp. growth and on its ochratoxin A production. The antifungal activity of compounds used as precursors of the dimeric species was also evaluated.

\section{Materials and methods}

Compound synthesis

The (2-amino-3-cyano-4H-chromene-4-yl)malononitrile $\mathbf{2 a}$ and $\mathbf{2 b}$ were synthesized from the corresponding substituted salicylaldehyde and malononitrile (two molar equivalents), in an aqueous $\mathrm{NaHCO}_{3} 0.05 \mathrm{~mol} \mathrm{~L}^{-1}$ solution, at room temperature (Scheme 1). The products were isolated in 91 to $100 \%$ yield after 5-35 min. The chromene dimer 3a was synthesized from malononitrile and salicylaldehyde in a 1:1 molar ratio, using methanol as solvent and triethylamine catalysis at room temperature. The yellow solid was isolated in $85 \%$ yield after 1 day. The chromene dimer $\mathbf{3 b}$ was generated from the reaction of malononitrile and 3-methoxysalicylaldehyde in a 1:1 ratio, using methanol as solvent and two drops of triethylamine. The solid mixture isolated after $6 \mathrm{~h}$ at room temperature was stirred in dimethyl sulfoxide (DMSO) solution for a further 21 days and isolated in $76 \%$.
Compounds characterization

All compounds were characterized by elemental analysis, melting point and IR spectroscopy (Table 1). Elemental analysis was performed on a LECO CHNS-932 instrument. Melting points were determined using a Gallenkamp melting point apparatus and are uncorrected. The IR spectra were obtained with an FT-IR Bomem-MB104 spectrophotometer using Nujol mulls and $\mathrm{NaCl}$ plates.

Bioassay of fungicidal activities

\section{Biological material}

Fungi used were Aspergillus alliaceus strain MUM 03.55, A. carbonarius strain MUM 03.59, A. niger strain MUM 03.58 and A. ochraceus strain MUM 03.56; all preserved in the Micoteca da Universidade do Minho (MUM) culture collection. The A. alliaceus, A. carbonarius and A. ochraceus strains are OTA producers, whereas the A. niger strain is not [15].

\section{In vitro assays}

The antifungal activity of synthesized compounds was evaluated at various concentrations by the poisoned food technique using YES medium (2\% yeast extract from Difco, $15 \%$ sucrose and $2 \%$ agar). Stock working solutions of the compounds were prepared in DMSO and aseptically
Scheme 1 General synthetic route for compounds 2 and 3

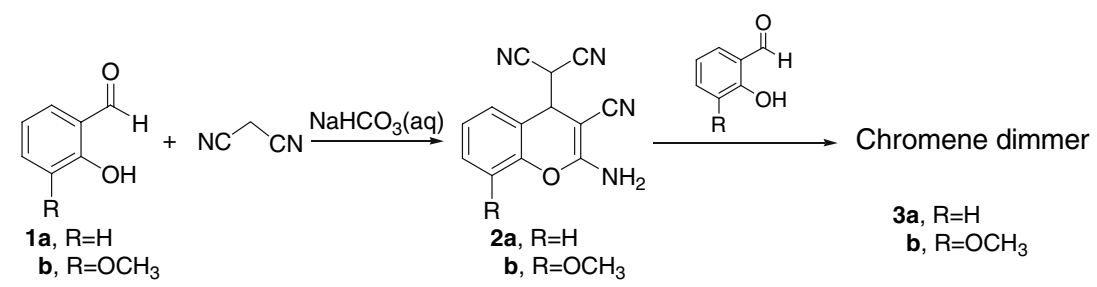

Table 1 Physical properties and elemental analysis of compounds $\mathbf{2}$ and $\mathbf{3}$

\begin{tabular}{|c|c|c|c|c|c|c|c|c|}
\hline \multirow[t]{2}{*}{ Compound } & \multirow[t]{2}{*}{$R$} & \multirow[t]{2}{*}{$\mathrm{Mp}\left({ }^{\circ} \mathrm{C}\right)$} & \multirow[t]{2}{*}{ Yield $(\%)$} & \multirow{2}{*}{$\begin{array}{l}\text { IR data }\left(\mathrm{cm}^{-1}\right) \\
\text { (Nujol mull) }\end{array}$} & \multirow[t]{2}{*}{ Formula } & \multicolumn{3}{|c|}{ Analysis calculated (found, \%) } \\
\hline & & & & & & $\mathrm{C}$ & $\mathrm{H}$ & $\mathrm{N}$ \\
\hline $2 \mathbf{a}$ & $\mathrm{H}$ & $152-153$ & 91.3 & $\begin{array}{l}2,195(\mathrm{~s}), 2,144(\mathrm{w}) \\
1,644(\mathrm{~s}), 1,615(\mathrm{w}) \\
1,603(\mathrm{~m}), 1,576(\mathrm{~s})\end{array}$ & $\mathrm{C}_{13} \mathrm{H}_{8} \mathrm{~N}_{4} \mathrm{O} \cdot 0.1 \mathrm{H}_{2} \mathrm{O}$ & $66.1(66.0)$ & $3.4(3.5)$ & $23.7(23.7)$ \\
\hline $2 \mathbf{b}$ & $\mathrm{OCH}_{3}$ & $168-169$ & 99.8 & $\begin{array}{l}2,253(\mathrm{w}), 2,192(\mathrm{~s}) \\
1,642(\mathrm{~s}), 1,614(\mathrm{~s}) \\
1,602(\mathrm{~s}), 1,583(\mathrm{~s})\end{array}$ & $\mathrm{C}_{14} \mathrm{H}_{10} \mathrm{~N}_{4} \mathrm{O}_{2} \cdot 0.1 \mathrm{H}_{2} \mathrm{O}$ & $63.2(63.1)$ & $3.7(3.8)$ & $21.1(20.9)$ \\
\hline 3a & $\mathrm{H}$ & $165-168$ & 84.5 & $\begin{array}{l}2,225(\mathrm{~m}), 2,196(\mathrm{~s}) \\
1,668(\mathrm{~m}), 1,650(\mathrm{~s}) \\
1,610(\mathrm{~m}), 1,578(\mathrm{~m})\end{array}$ & $\mathrm{C}_{20} \mathrm{H}_{12} \mathrm{~N}_{4} \mathrm{O}_{2} \cdot 0.1 \mathrm{H}_{2} \mathrm{O}$ & $70.2(70.2)$ & $3.6(3.6)$ & $16.4(16.6)$ \\
\hline $3 \mathbf{b}$ & $\mathrm{OCH}_{3}$ & $150-152$ & 75.7 & $\begin{array}{l}2,227(\mathrm{~m}), 2,189(\mathrm{~s}) \\
1,642(\mathrm{~s}), 1,602(\mathrm{~m}) \\
1,585(\mathrm{~m})\end{array}$ & $\mathrm{C}_{22} \mathrm{H}_{16} \mathrm{~N}_{4} \mathrm{O}_{4} \cdot \mathrm{C}_{2} \mathrm{H}_{6} \mathrm{SO} \cdot 1 / 2 \mathrm{H}_{2} \mathrm{O}$ & $59.14(59.18)$ & $4.72(5.03)$ & $11.50(11.74)$ \\
\hline
\end{tabular}


added to the autoclaved culture medium to reach 50,100 and $200 \mu \mathrm{mol} \mathrm{L}^{-1}$, before plating $20 \mathrm{~mL}$ in $9 \mathrm{~cm}$ petri dishes. Culture media supplemented with DMSO were used as control. Strains were first grown in MEA medium (Blakeslee formula) for 7 days at $25{ }^{\circ} \mathrm{C}$ in the dark for inoculum generation. Spore suspensions were prepared in $1 \mathrm{~mL}$ of semi solid agar $(0.2 \%$ agar and $0.05 \%$ Tween 80$)$, and its concentrations were adjusted to $2.5 \times 10^{6}$ spores $\mathrm{mL}^{-1}$, using a NeuBauer chamber. Plates were centrally inoculated with $10 \mu \mathrm{L}$ of each spore suspension and incubated at $25{ }^{\circ} \mathrm{C}$ in the dark. All experiments were in triplicate for each compound against each fungus. Fungal colony diameters were recorded daily. Growth rates were calculated by linear regression of colony diameters against days. The concentration of active ingredient at which survival was $50 \%\left(\mathrm{EC}_{50}\right)$ was determined by fitting the experimental data to a four-parameter logistic model (Hill equation) using computer curve-fitting software (Prism 4, GraphPad Software, Inc, San Diego, CA, USA). A microplate assay was also prepared to determine the concentration of 3a necessary to totally inhibit spore germination of the tested strains. In a sterile 96-well microplate, assays with 0 (controls) to $2,000 \mu \mathrm{mol} \mathrm{L}^{-1}$ of $\mathbf{3 a}$, in $200 \mu \mathrm{L}$ of YES medium previously inoculated with each strain, were prepared in duplicate. The microplate was incubated at $25^{\circ} \mathrm{C}$, in the dark, for 6 days, and a visual observation was done each day to record the presence of mycelia. To evaluate fungal growth in each well, different values were given: a value of 1 to wells totally covered with fungal mycelia, 0.5 when just half of the well was covered, and 0.25 when $1 / 4$ of the well was covered.

\section{Ochratoxin A detection}

The OTA produced by the ochratoxigenic strains in the experiments of the poisoned food technique was quantified after 6 days of fungal growth. Media and colonies were cut in small pieces and transferred to $50 \mathrm{~mL}$ Greiner tubes. Twenty milliliters of methanol were added and, after strong agitation, left to extract overnight. Three milliliters of extract was filtered through a $0.45 \mu \mathrm{m}$ syringe filter of PTFE (Teknokroma) and $1 \mathrm{~mL}$ of the filtrate evaporated to dryness at $50{ }^{\circ} \mathrm{C}$ with a gentle stream of nitrogen in a clean vial. Dry extracts were resuspended in $1 \mathrm{~mL}$ of HPLC mobile phase and analyzed by high-performance liquid chromatography. The HPLC apparatus consisted of a Varian 9002 pump equipped with a Jasco FP-920 fluorescence detector $\left(\lambda_{\mathrm{ex}}=333 \mathrm{~nm} ; \lambda_{\mathrm{em}}=460 \mathrm{~nm}\right)$ and a Marathon Basic autosampler. The analytical column was a $\mathrm{C}_{18}$ reversed-phase YMC-Pack ODS-AQ $(250 \times 4.6 \mathrm{~mm}$ and $5 \mu \mathrm{m})$, fitted with a precolumn with the same stationary phase. The mobile phase was a mixture of acetonitrile/ water/acetic acid (99/99/2, v/v/v), filtered and degassed.
Flow rate was set to $0.8 \mathrm{~mL} \mathrm{~min}^{-1}$ and the column temperature to $30^{\circ} \mathrm{C}$; the loop volume was $100 \mu \mathrm{L}$. A five-point calibration curve was prepared with standards of ochratoxin A (Sigma) and regularly checked.

\section{Statistic analysis}

All statistic analyses were performed with the Statistic Package for Social Sciences (SPSS) version 15.0. Means were compared by analysis of variance followed by the Ducan's post-test.

\section{Results}

The growth rates of strains in the presence of tested compounds are summarized in Table 2. Compound 3a was the only one to show a significant antifungal activity on all strains assessed. It was more effective on Aspergillus alliaceus, producing growth rates reductions from $2.05 \mathrm{~cm} \mathrm{day}^{-1}$ to $1.02,1.01$ and $0.66 \mathrm{~cm} \mathrm{day}^{-1}$ in the presence of 50,100 and $200 \mu \mathrm{mol} \mathrm{L}{ }^{-1}$, respectively. Aspergillus carbonarius was less sensitive to 3a. Significant reductions of growth rates from $2.22 \mathrm{~cm} \mathrm{day}^{-1}$ to $2.18,1.98$ and $1.70 \mathrm{~cm} \mathrm{day}^{-1}$ in the presence of 50,100 and $200 \mu \mathrm{mol} \mathrm{L}^{-1}$, respectively, were obtained for this strain. The effect of $\mathbf{3 a}$ in the mycelial growth of fungi tested after 4 days of incubation can be observed in the Fig. 1. The concentration of $\mathbf{3 a}$ at which survival was $50 \%\left(\mathrm{EC}_{50}\right)$ is $140.1 \mu \mathrm{mol} \mathrm{L}-1$ for A. niger, $384.2 \mu \mathrm{mol} \mathrm{L}^{-1}$ for A. carbonarius, $69.1 \mu \mathrm{mol} \mathrm{L}^{-1}$ for $A$. alliaceus and $559.1 \mu \mathrm{mol} \mathrm{L}^{-1}$ for A. ochraceus (Table 3). Furthermore, it was observed that $2,000 \mu \mathrm{mol} \mathrm{L}^{-1}$ of $\mathbf{3 a}$ totally inhibit the spore germination of tested fungi since mycelial growth was not observed in the 96-well microplate tests, as it can be seen in Fig. 2. Lower amounts of this compound (500 and 1,000 $\mu \mathrm{mol} \mathrm{L}^{-1}$ ) increase the lag time, since visible mycelia only appear at the third and fourth day of incubation. No significant inhibition on growth rates was registered for compounds $\mathbf{2 a}$ and $\mathbf{2} \mathbf{b}$, used as synthetic precursors of the dimeric species $\mathbf{3} \mathbf{a}$ and $\mathbf{3 b}$.

The effect of compounds on ochratoxin A production is shown in Table 4 . The production of OTA by A. alliaceus was significantly reduced by compounds $\mathbf{3 a}$ and $\mathbf{3 b}$. In the presence of 50,100 and $200 \mu \mathrm{mol} \mathrm{L}^{-1}$ of $\mathbf{3 a}$, A. alliaceus produced 290.1, 229.9 and $25.4 \mu \mathrm{g}$ OTA/plate; respectively, less 32, 46 and $94 \%$ than control (427.04 $\mu \mathrm{g}$ OTA/plate). In the presence of $200 \mu \mathrm{mol} \mathrm{L}^{-1}$ of $\mathbf{3 b}$ A. alliaceus produced $222.73 \mu \mathrm{g}$ OTA/ plate, less $48 \%$ than control. Significant reduction in OTA production by $A$. carbonarius was also observed with $\mathbf{3 b}$. In the presence of $200 \mu \mathrm{mol} \mathrm{L}^{-1}$ of $\mathbf{3 b}$, A. carbonarius produced $6.38 \mu \mathrm{g}$ OTA/plate, less $61 \%$ than control (16.43 $\mu \mathrm{g}$ OTA/ plate). The effect of compounds $\mathbf{3 a}$ and $\mathbf{3 b}$ on OTA production by $A$. ochraceus was not significant. 
Table 2 Radial growth rates $\left(\mathrm{cm} \mathrm{day}^{-1}\right)$ of tested strains in YES supplemented with the synthesized compounds

Values are the mean of three replicates of each \pm standard deviation (SD). Data marked with different letters are significantly different from respective control at $P<0.001$ for the Duncan test

Fig. 1 Effect of 50, 100 and $200 \mu \mathrm{mol} \mathrm{L}{ }^{-1}$ of compound 3a on the mycelia growth of tested fungi after 4 days of incubation at $25{ }^{\circ} \mathrm{C}$

\begin{tabular}{|c|c|c|c|c|c|}
\hline \multirow[t]{2}{*}{ Compound } & \multirow[t]{2}{*}{$\mu \mathrm{mol} \mathrm{L}{ }^{-1}$} & \multicolumn{4}{|c|}{ Radial growth rates $\left(\mathrm{cm} \mathrm{day}^{-1}\right)$} \\
\hline & & A. niger & A. carbonarius & A. lalliaceus & A. ochraceus \\
\hline \multicolumn{2}{|l|}{ Control } & $2.13 \pm 0.05^{\mathrm{a}}$ & $2.22 \pm 0.03^{\mathrm{a}}$ & $2.05 \pm 0.02^{\mathrm{a}}$ & $1.45 \pm 0.02^{\mathrm{a}}$ \\
\hline \multirow[t]{3}{*}{$3 a$} & 50 & $1.25 \pm 0.02^{\mathrm{d}}$ & $2.18 \pm 0.03^{\mathrm{b}}$ & $1.02 \pm 0.05^{\mathrm{c}}$ & $1.33 \pm 0.02^{\mathrm{b}}$ \\
\hline & 100 & $1.13 \pm 0.03^{\mathrm{e}}$ & $1.98 \pm 0.04^{\mathrm{c}}$ & $1.01 \pm 0.02^{\mathrm{c}}$ & $1.26 \pm 0.02^{\mathrm{c}}$ \\
\hline & 200 & $1.06 \pm 0.03^{\mathrm{e}}$ & $1.70 \pm 0.03^{\mathrm{d}}$ & $0.66 \pm 0.02^{\mathrm{d}}$ & $1.08 \pm 0.02^{\mathrm{d}}$ \\
\hline \multirow[t]{3}{*}{$2 \mathrm{a}$} & 50 & $1.98 \pm 0.06^{\mathrm{b}}$ & $2.27 \pm 0.02^{\mathrm{a}}$ & $1.98 \pm 0.03^{\mathrm{a}, \mathrm{b}}$ & $1.44 \pm 0.01^{\mathrm{a}}$ \\
\hline & 100 & $1.94 \pm 0.02^{\mathrm{b}}$ & $2.27 \pm 0.02^{\mathrm{a}}$ & $1.98 \pm 0.01^{\mathrm{a}, \mathrm{b}}$ & $1.44 \pm 0.01^{\mathrm{a}}$ \\
\hline & 200 & $1.80 \pm 0.03^{\mathrm{c}}$ & $2.21 \pm 0.02^{\mathrm{a}, \mathrm{b}}$ & $1.86 \pm 0.02^{\mathrm{b}}$ & $1.41 \pm 0.01^{\mathrm{a}}$ \\
\hline \multirow[t]{3}{*}{$3 b$} & 50 & $2.03 \pm 0.02^{\mathrm{a}, \mathrm{b}}$ & $2.17 \pm 0.02^{\mathrm{b}}$ & $2.00 \pm 0.02^{\mathrm{a}, \mathrm{b}}$ & $1.41 \pm 0.02^{\mathrm{a}}$ \\
\hline & 100 & $2.00 \pm 0.02^{\mathrm{a}, \mathrm{b}}$ & $2.22 \pm 0.04^{\mathrm{a}}$ & $1.98 \pm 0.01^{\mathrm{a}, \mathrm{b}}$ & $1.40 \pm 0.03^{\mathrm{a}}$ \\
\hline & 200 & $1.83 \pm 0.05^{\mathrm{b}, \mathrm{c}}$ & $2.14 \pm 0.02^{\mathrm{b}}$ & $2.02 \pm 0.04^{\mathrm{a}, \mathrm{b}}$ & $1.33 \pm 0.05^{\mathrm{b}}$ \\
\hline \multirow[t]{3}{*}{$2 b$} & 50 & $2.14 \pm 0.03^{\mathrm{a}}$ & $2.21 \pm 0.02^{\mathrm{a}, \mathrm{b}}$ & $2.06 \pm 0.02^{\mathrm{a}}$ & $1.42 \pm 0.02^{\mathrm{a}}$ \\
\hline & 100 & $2.10 \pm 0.08^{\mathrm{a}, \mathrm{b}}$ & $2.20 \pm 0.02^{\mathrm{a}, \mathrm{b}}$ & $2.09 \pm 0.02^{\mathrm{a}}$ & $1.44 \pm 0.02^{\mathrm{a}}$ \\
\hline & 200 & $2.04 \pm 0.02^{\mathrm{a}, \mathrm{b}}$ & $2.19 \pm 0.01^{\mathrm{b}}$ & $2.11 \pm 0.06^{\mathrm{a}}$ & $1.38 \pm 0.03^{\mathrm{a}, \mathrm{b}}$ \\
\hline
\end{tabular}

Control

50

100

200

$\mathrm{mol} \mathrm{L}^{-1}$

$\mathrm{mol} \mathrm{L}^{-1}$

$\mathrm{mol} \mathrm{L}^{-1}$

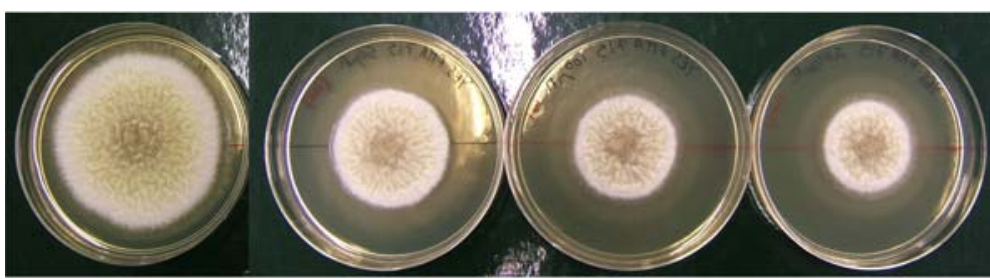

A. niger

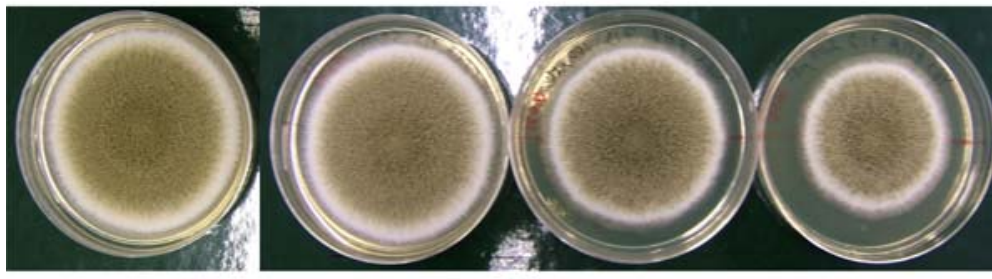

A. carbonarius

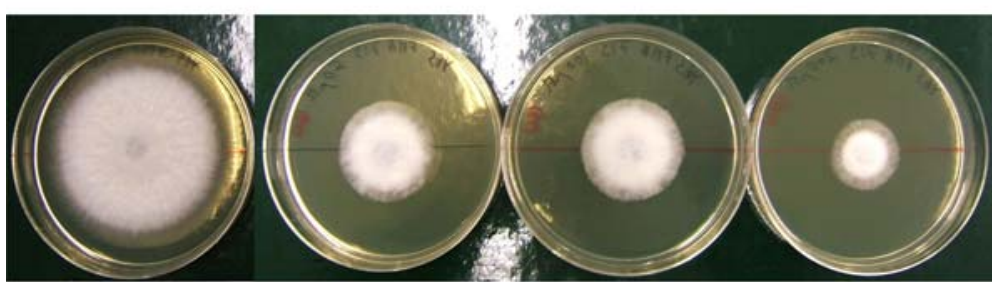

A. alliaceus

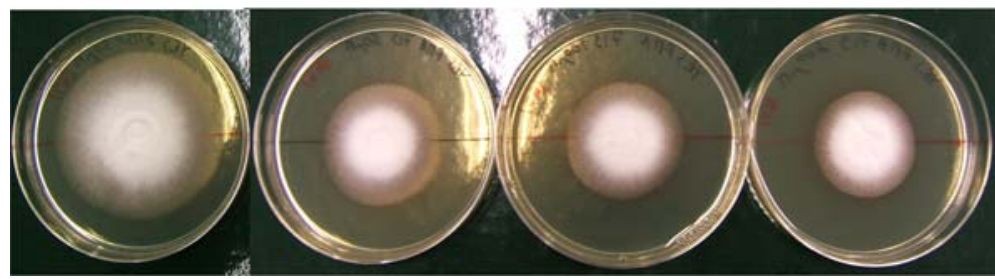

A. ochraceus 
Table 3 The $50 \%$ effective concentration $\left(\mathrm{EC}_{50}\right)$ of compound $\mathbf{3 a}$ for the different Aspergillus spp. tested

\begin{tabular}{lrll}
\hline & $\mathrm{EC}_{50}{ }^{\mathrm{a}}$ & $95 \% \mathrm{CI}^{\mathrm{b}}$ & $r^{2 \mathrm{c}}$ \\
\hline A. niger & 140.1 & 107.1 to 183.3 & 0.9578 \\
A. carbonarius & 384.2 & 327.7 to 450.4 & 0.9782 \\
A. alliaceus & 69.1 & 53.6 to 89.2 & 0.9620 \\
A. ochraceus & 559.1 & 437.0 to 715.4 & 0.9784
\end{tabular}

${ }^{a} \mathrm{EC}_{50}=$ concentration of active ingredient $\left(\mu \mathrm{mol} \mathrm{L}{ }^{-1}\right)$ at which survival was $50 \%$ as determined by fitting the experimental data to a fourparameter logistic model (Hill equation) using computer curve-fitting software (Prism 4, GraphPad Software, Inc, San Diego, CA, USA)

b $95 \%$ Confidence Intervals of fitted $\mathrm{EC}_{50}$

c Correlation coefficient of fitted curves

\section{Discussion}

Novel chromene derivatives, obtained by new chemistry, were evaluated for their antifungal properties against selected toxigenic fungi. The novelty of these compounds relies on the very simple and straightforward synthesis and on the absence of halogen elements. This latter property makes these compounds more environmental friendly than some commercial fungicides. Furthermore, the chemistry of these compounds allows the preparation of chromene dimers with different radical in C8 (3a and $\mathbf{3 b}$ ), which could be useful in the manipulation of their activity.

The chromene dimer 3a was found to be the most effective of the tested compounds. A moderate inhibitory effect was also observed for the analogue structure $\mathbf{3 b}$ but only for the inhibition of ochratoxin A production. No effect was registered for compounds $\mathbf{2 a}$ and $\mathbf{2 b}$, used as synthetic precursors of the dimeric species $\mathbf{3}$. These results suggest that the dimeric structure is essential to the antifungal activity of species 3 . The highly toxic strain of A. alliaceus was found to be the most sensitive to compound 3a since $200 \mu \mathrm{mol} \mathrm{L}{ }^{-1}$ of this compound was sufficient to inhibit its radial growth by $68 \%$ and its ochratoxin A production by nearly $94 \%$.

Recently, Bellí and coworkers [3] tested the effect of several commercial fungicides on A. carbonarius strains. In their work, concentrations from 0.035 to $4.0 \mathrm{~g} \mathrm{~L}^{-1}$ were used, depending on the product and as recommended by manufacturers. From 26 products tested, only half of them totally inhibited the growth of the tested strains. In our work, $2000 \mu \mathrm{mol} \mathrm{L}^{-1}$ of $\mathbf{3 a}$, which represents $0.681 \mathrm{~g} \mathrm{~L}^{-1}$, inhibit all the tested strains. So, the antifungal capacity of 3a is comparable to some of the commercial products used by Bellí and coworkers [3], leading to the conclusion that 3a may have success as a fungi-controlling agent for field applications.
Fig. 2 Presence of visible mycelia when a A. alliaceus, b A. ochraceus, $\mathbf{c}$ A. carbonarius and $\mathbf{d} A$. niger were cultivated in YES medium supplemented with different concentrations of compound 3a on a 96-well microplate
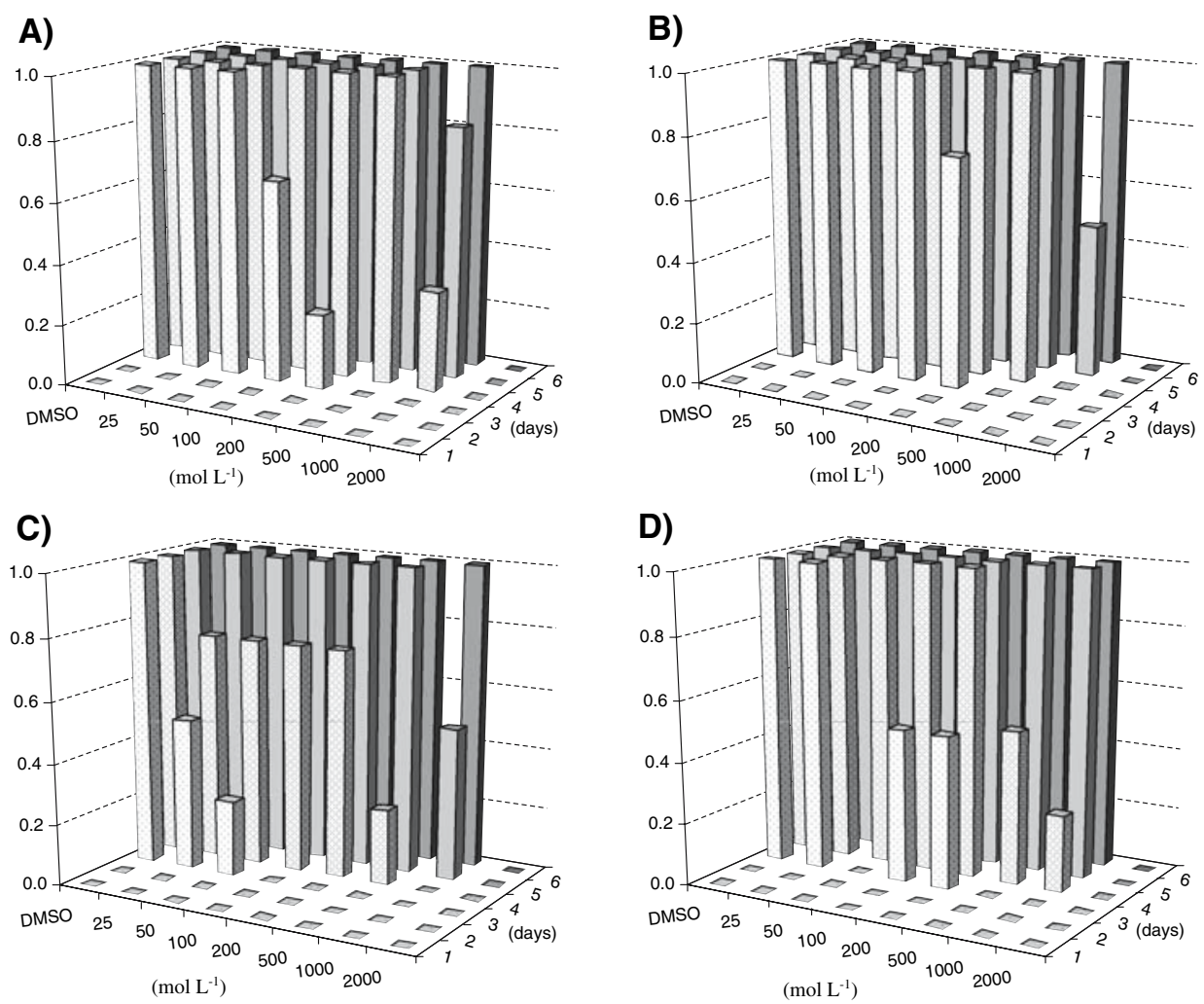

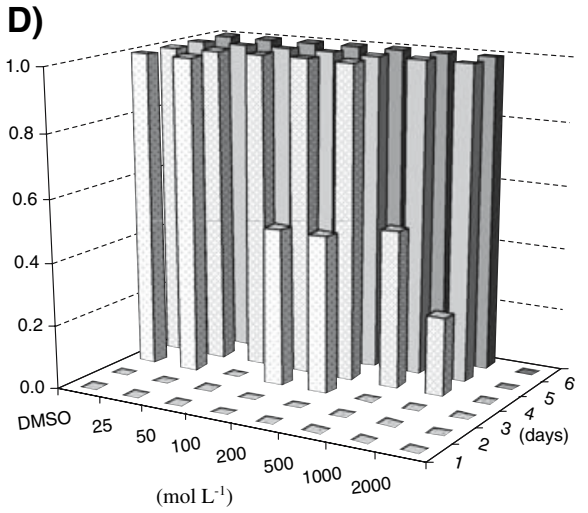


Table 4 Effect of the compounds in the production of ochratoxin A

Values are the mean of three replicates of each \pm standard deviation (SD). Data marked with different letters are significantly different from respective control at $P<0.05$ for the Duncan test

\begin{tabular}{|c|c|c|c|c|}
\hline \multirow[t]{2}{*}{ Compound } & \multirow[t]{2}{*}{$\mu \mathrm{mol} \mathrm{L}-1$} & \multicolumn{3}{|c|}{ Ochratoxin A contents ( $\mu \mathrm{g} /$ plate) } \\
\hline & & A. carbonarius & A. alliaceus & A. ochraceus \\
\hline Control & & $16.43 \pm 4.38^{\mathrm{a}, \mathrm{b}}$ & $427.04 \pm 83.02^{\mathrm{b}}$ & $38.29 \pm 13.90^{\mathrm{a}}$ \\
\hline \multirow[t]{3}{*}{$3 \mathrm{a}$} & 50 & $21.40 \pm 2.26^{\mathrm{a}}$ & $290.13 \pm 37.99^{c}$ & $45.05 \pm 6.52^{\mathrm{a}}$ \\
\hline & 100 & $22.14 \pm 1.44^{\mathrm{a}}$ & $229.87 \pm 24.62^{\mathrm{d}}$ & $53.71 \pm 4.86^{\mathrm{a}}$ \\
\hline & 200 & $19.72 \pm 3.84^{\mathrm{a}}$ & $25.40 \pm 15.68^{\mathrm{e}}$ & $43.96 \pm 11.19^{\mathrm{a}}$ \\
\hline $2 \mathrm{a}$ & 200 & $25.45 \pm 5.31^{\mathrm{a}}$ & $427.64 \pm 12.24^{\mathrm{b}}$ & $33.69 \pm 8.12^{\mathrm{a}}$ \\
\hline $3 b$ & 200 & $6.38 \pm 3.49^{\mathrm{c}}$ & $222.73 \pm 34.86^{\mathrm{d}}$ & $48.76 \pm 3.09^{\mathrm{a}}$ \\
\hline $2 b$ & 200 & $19.04 \pm 5.06^{\mathrm{a}, \mathrm{b}}$ & $501.37 \pm 6.31^{\mathrm{a}}$ & $43.36 \pm 12.22^{\mathrm{a}}$ \\
\hline
\end{tabular}

Acknowledgment Luís Abrunhosa is grateful for grant SFRH/BD/ 11228/2002 from Fundação para a Ciência e Tecnologia-FCT, Portugal.

\section{References}

1. Abd-El-Aziz AS, El Agrody AM, Bedair AH, Corkery TC, Ata A (2004) Synthesis of hydroxyquinoline derivatives, amino-hydroxychromene, aminocoumarin and their antibacterial activities. Heterocycles 63:1793-1812

2. Bayman P, Baker JL, Doster MA, Michailides TJ, Mahoney NE (2002) Ochratoxin production by the Aspergillus ochraceus group and Aspergillus alliaceus. Appl Environ Microbiol 68:2326-2329

3. Bellí N, Marín S, Sanchis V, Ramos AJ (2006) Impact of fungicides on Aspergillus carbonarius growth and ochratoxin A production on synthetic grape-like medium and on grapes. Food Addit Contam 23:1021-1029

4. Borges F, Roleira F, Milhazes N, Santana L, Uriarte E (2005) Simple coumarins and analogues in medicinal chemistry: occurrence, synthesis and biological activity. Curr Med Chem 12:887-916

5. Chimenti F, Bizzarri B, Bolasco A, Secci D, Chimenti P, Carradori S, Granese A, Rivanera D, Lilli D, Scaltrito MM, Brenciaglia MI (2006) Synthesis and in vitro selective anti-Helicobacter pylori activity of N-substituted-2-oxo-2H-1-benzopyran-3-carboxamides. Eur J Med Chem 41:208-212

6. Curini M, Cravotto G, Epifano F, Giannone G (2006) Chemistry and biological activity of natural and synthetic prenyloxycoumarins. Curr Med Chem 13:199-222

7. D`Mello JPF, Macdonald AMC, Postel D, Dijksma WTP, Dujardin A, Placinta CM (1998) Pesticide use and mycotoxin production in Fusarium and Aspergillus phytopathogens. Eur J Plant Pathol 104:741-751

8. El Agrody AM, El-Latif MSA, El-Hady NA, Fakery AH, Bedair AH (2001) Heteroaromatization with 4-Hydroxycoumarin Part II: synthesis of some new Pyrano[2,3-d]pyrimidines, [1,2,4]triazolo[1,5-c]pyrimidines and Pyrimido[1,6-b]-[1,2,4]triazine derivatives. Molecules 6:519-527

9. Khan KM, Saify ZS, Khan MZ, Zia-Ullah, Choudhary MI, Attaur-Rahman, Perveen S, Chohan ZH, Supuran CT (2004) Synthesis of coumarin derivatives with cytotoxic, antibacterial and antifungal activity. J Enzyme Inhib Med Chem 19:373-379

10. Knight SC, Anthony VM, Brady AM, Greenland AJ, Heaney SP, Murray DC, Powell KA, Schulz MA, Spinks CA, Worthington PA, Youle D (1997) Rationale and perspectives on the development of fungicides. Annu Rev Phytopathol 35:349-372

11. Kulkarni MV, Kulkarni GM, Lin CH, Sun CM (2006) Recent advances in coumarins and 1-azacoumarins as versatile biodynamic agents. Curr Med Chem 13:2795-2818

12. Larsen TO, Svendsen A, Smedsgaard J (2001) Biochemical characterization of Ochratoxin A-producing strains of the genus Penicillium. Appl Environ Microbiol 67:3630-3635

13. Lund F, Frisvad JC (2003) Penicillium verrucosum in wheat and barley indicates presence of Ochratoxin A. J Appl Microbiol 95:1117-1123

14. Pitt JI, Taniwaki MH, Teixeira AA, Iamanaka BT (2001) Distribution of Aspergillus ochraceus, A. niger and A. carbonarius in coffee in four regions of Brazil. In: 19th Colloquium: Moisture Management for Mould Prevention in Coffee

15. Serra R, Abrunhosa L, Kozakiewicz Z, Venâncio A (2003) Black Aspergillus species as ochratoxin A producers in Portuguese wine grapes. Int J Food Microbiol 88:63-68

16. Simpson DR, Weston GE, Turner JA, Jennings $\mathrm{P}$, Nicholson $\mathrm{P}$ (2001) Differential control of head blight pathogens of wheat by fungicides and consequences for mycotoxin contamination of grain. Eur J Plant Pathol 107:421-431

17. Yu DL, Suzuki M, Xie L, Morris-Natschke SL, Lee KH (2003) Recent progress in the development of coumarin derivatives as potent anti-HIV agents. Med Res Rev 23:322-334 